\title{
ANTHROPOGENIC FACTORS IN LAND-USE CHANGE IN CHINA
}

Gerhard K. Heilig

International Institute for Applied Systems Analysis

Laxenburg, Austria

RR-97-8

June 1997

Reprinted from Population and Development Review 23(1):139-168 (March 1997).

International Institute for Applied Systems Analysis, Laxenburg, Austria Tel: +432236 807 Fax: +43223673148 E-mail: publications@iiasa.ac.at 
Research Reports, which record research conducted at IIASA, are independently reviewed before publication. Views or opinions expressed herein do not necessarily represent those of the Institute, its National Member Organizations, or other organizations supporting the work.

Reprinted with the permission of the Population Council, from Population and Development Review 23(1):139-168 (March 1997).

Copyright (c) 1997 by the Population Council

All rights reserved. No part of this publication may be reproduced or transmitted in any form or by any means, electronic or mechanical, including photocopy, recording, or any information storage or retrieval system, without permission in writing from the copyright holder. 


\title{
DATA AND PERSPECTIVES
}

\section{Anthropogenic Factors in Land-Use Change in China}

\author{
GERHARD K. HEILIG
}

THERE ARE FEW places in the world where people have changed the land so intensely and for such a long time as in China (Perkins 1969). Much of the country's inhabited land had been transformed by human intervention several hundred years ago. The Loess Plateau of northern China, for instance, was completely deforested in preindustrial times (Fang and Xie 1994). During the early Han Dynasty, in the fourth and third centuries BC, the Chinese started systematic land reclamation and irrigation schemes, converting large areas of natural land into rice paddies. The process, which was scientifically planned and coordinated by subsequent dynastic bureaucracies, reached a first climax in the eleventh and twelfth centuries (Braudel 1990: 159). In the second half of the eighteenth and first half of the nineteenth century, another period of massive land modification followed.

\section{Some recent land-cover and land-use data}

Analyzing land-use data for China is not an easy task. Almost every source has different estimates, even for the most basic statistics. Sometimes the differences are minor or can be explained, sometimes they are beyond comprehension. The data presented below are from various Chinese sources and reflect this situation. I first describe the figures and highlight some of the discrepancies; I then try to explain and evaluate.

Table 1 presents basic statistics as they were published in a recent book on land use in China by Wu and Guo (1994). For comparison the table also includes land-use estimates by Sun et al. (1994) as well as "official" figures from the 1994 Statistical Yearbook of China. 
TABLE 1 Land use and land cover in China according to three sources

\begin{tabular}{|c|c|c|c|c|c|}
\hline & \multicolumn{3}{|c|}{ Wu and Guo 1994: 91} & \multirow{2}{*}{$\begin{array}{l}\text { Sun et al. } \\
\text { 1994: } 165 \\
\text { Area } \\
\text { (in million } \\
\text { ha) }\end{array}$} & \multirow{2}{*}{$\begin{array}{l}\text { Statistical } \\
\text { Yearbook of } \\
\text { China 1994: } 5 \\
\text { Area } \\
\text { (in million } \\
\text { ha) }\end{array}$} \\
\hline & $\begin{array}{l}\text { Area } \\
\text { (in } \\
\text { million ha) }\end{array}$ & $\begin{array}{l}\text { Percent of } \\
\text { total land } \\
\text { area }\end{array}$ & $\begin{array}{l}\text { Percent of } \\
\text { cultivated } \\
\text { land }\end{array}$ & & \\
\hline Total land area & 960.0 & 100.0 & & & 960.0 \\
\hline 1 Cropland & 136.4 & 14.2 & 100.0 & 133.3 & $95.1^{f}$ \\
\hline 2 Horticulture & 7.4 & 0.8 & & & \\
\hline 3 Forests/woodland & 195.4 & 20.4 & & $167.2^{\mathrm{a}}$ & 128.6 \\
\hline 4 Grassland/prairie & 338.6 & 35.3 & & 400 & 400.0 \\
\hline $\begin{array}{l}\text { Agricultural land } \\
\text { (Total: } 1-4)\end{array}$ & 677.8 & 70.6 & & & \\
\hline $\begin{array}{l}5 \text { Cities/towns/ } \\
\text { industry }\end{array}$ & 1.9 & 0.2 & 1.4 & & \\
\hline 6 Rural settlements & 23.5 & 2.4 & 17.2 & & \\
\hline 7 Infrastructure & 7.1 & 0.7 & 5.2 & & \\
\hline $\begin{array}{l}\text { Nonagricultural land } \\
\text { (Total: } 5-7 \text { ) }\end{array}$ & 32.4 & 3.4 & 23.8 & $26.5^{b}$ & \\
\hline $\begin{array}{l}8 \text { Inland water bodies/ } \\
\text { fish ponds }\end{array}$ & 32.5 & 3.4 & & $17.6^{c}$ & 17.5 \\
\hline 9 Tidal marshes & 2.2 & 0.2 & & & \\
\hline (Total: 8-9) & 34.7 & 3.6 & & & \\
\hline 10 Glacier/snow & 6.9 & 0.7 & & $5.9^{d}$ & \\
\hline 11 Sandy desert & 46.7 & 4.9 & & & \\
\hline $\begin{array}{l}12 \text { Stonel } \\
\text { rock desert (e.g. Gobi) }\end{array}$ & 30.4 & 3.2 & & & \\
\hline $\begin{array}{l}13 \text { Other (marginal) } \\
\text { land/mountains }\end{array}$ & 131.2 & 13.7 & & $185.3^{e}$ & \\
\hline (Total: 10-13) & 215.1 & 22.4 & & & $318.8^{\mathrm{g}}$ \\
\hline
\end{tabular}

NOTE: In Wu and Guo, cropland includes paddy rice, irrigated, and rainfed cropland; in Sun et al., the data refer to cultivated land, which includes horticulture.

a Forest land and shrubs b Residential areas, industry, mining, transportation, etc. 'Inland water surface

dice-covered land e Bare land $\quad{ }^{\prime}$ Known to be underestimated, according to Statistical Yearbook 8 All other land

China has a total land area of 960 million hectares (9.6 million $\mathrm{km}^{2}$ ). According to Wu and Guo, some 15 percent is cultivated, about 20 percent is forest and woodland, and grassland covers some 35 percent. More than 22 percent of China's land area is covered by sandy or stony desert (the Gobi being the largest), glaciers and permanent snow, and other marginal lands. Cities, towns, industrial sites, rural settlements, and infrastructure cover some 3.4 percent of the land area.

These data differ from official statistics (as published in the Statistical Yearbook of China) and from estimates by other authors in several important respects: 
-The reported forest/woodland area is larger than the estimates of either Sun et al. or the Statistical Yearbook.

-Inland water bodies and fish ponds are also estimated to be larger in size than in the two other sources.

-The estimate for grassland is 60 million hectares smaller than those from Sun et al. and the Statistical Yearbook.

-Infrastructure, rural and urban settlements, and mining and industrial areas are somewhat larger than in Sun et al.

-The most important difference, however, relates to the estimate of cultivated land in Wu and Guo, which is much higher than in the Statistical Yearbook, but comparable to the estimate of Sun et al. This is due to a wellknown problem of underreporting in the Statistical Yearbook, which I discuss later.

In addition to their own estimates, presented in Table 1, Wu and Guo use data from the Statistical Yearbook (including the underreported "cultivated land" statistics) to ascertain changes in land use since 1949, shown in Table 2. According to these official data, the largest change was in forest land, which was extended by 70 million hectares. Other sources have indicated a decline of China's forest and woodland. A possible explanation for the discrepancy is that primary forests in China in fact declined, while the total forest area increased due to new plantings. On the other hand, most experts agree that China's marginal land ("other land") and grassland declined. Wu and Guo estimated the decline at roughly 59 million hectares and 53 million hectares, respectively.

The next largest change in land use was the expansion of settlement areas, mining sites, and transportation infrastructure. According to Wu and Guo these areas increased by about 26 million hectares between 1949 and 1990. By far the largest proportional change of land use in China was the

TABLE 2 Changes in land use in China, 1949 and 1990 (in million hectares)

\begin{tabular}{lrrrr}
\hline & $\mathbf{1 9 4 9}$ & $\mathbf{1 9 9 0}$ & $\begin{array}{l}\text { Absolute } \\
\text { change }\end{array}$ & $\begin{array}{l}\text { Percent } \\
\text { change }\end{array}$ \\
\hline $\begin{array}{l}\text { Forest and woodland } \\
\begin{array}{l}\text { Settlements, mining, } \\
\text { and transportation }\end{array}\end{array}$ & 125.0 & 195.4 & 70.4 & 56.3 \\
$\quad$ infrastructure & & & & \\
Water bodies & 6.7 & 32.8 & 26.1 & 387.1 \\
Horticulture & 22.5 & 34.1 & 11.5 & 51.2 \\
Cultivated (crop) land & 1.1 & 7.4 & 6.3 & 593.8 \\
Grassland & 97.9 & 95.7 & -2.2 & -2.2 \\
Other (marginal) land & 391.9 & 338.6 & -53.3 & -13.6 \\
\hline
\end{tabular}

NOTE: Differences between Tables 1 and 2 are in the original sources. SOURCE: Wu and Guo (1994): 77 
TABLE 3 Changes in cultivated land area by province, 1985 and 1995 (sorted by percentage change)

\begin{tabular}{|c|c|c|c|c|c|c|c|}
\hline \multirow[b]{2}{*}{ Province } & \multicolumn{2}{|c|}{$\begin{array}{l}\text { Cultivated area } \\
\text { (1000 ha) reported } \\
\text { in Statistical Yearbook }\end{array}$} & \multirow{2}{*}{$\begin{array}{l}\text { Correction } \\
\text { factor } \\
\text { (Wang et al.) }\end{array}$} & \multicolumn{2}{|c|}{$\begin{array}{l}\text { Corrected } \\
\text { cultivated area } \\
\text { (1000 ha) }\end{array}$} & \multirow{2}{*}{$\begin{array}{l}\text { Change } \\
\text { 1985-95 } \\
\text { (1000 ha) }\end{array}$} & \multirow{2}{*}{$\begin{array}{l}\text { Change } \\
\text { 1985-95 } \\
\text { (percent }\end{array}$} \\
\hline & 1985 & 1995 & & 1985 & 1995 & & \\
\hline Shanghai & 340 & 290 & 0.14 & 388 & 331 & -57.1 & -14.7 \\
\hline \multicolumn{5}{|l|}{ Guangdong/ } & 4,971 & -522.2 & -9.5 \\
\hline Zhejiang & 1,777 & 1,618 & 0.47 & 2,618 & 2,383 & -234.5 & -9.0 \\
\hline Shaanxi & 3,627 & 3,393 & 0.54 & 5,594 & 5,234 & -360.3 & -6.4 \\
\hline Hubei & 3,585 & 3,358 & 0.24 & 4,437 & 4,156 & -280.9 & -6.3 \\
\hline Liaoning & 3,586 & 3,390 & 0.26 & 4,507 & 4,260 & -246.7 & -5.5 \\
\hline Beijing & 421 & 400 & 0.26 & 531 & 504 & -27.1 & -5.1 \\
\hline Shandong & 7,038 & 6,696 & 0.30 & 9,137 & 8,693 & -444.0 & -4.9 \\
\hline Tianjin & 447 & 426 & 0.38 & 617 & 588 & -28.8 & -4.7 \\
\hline Fujian & 1,261 & 1,204 & 0.31 & 1,646 & 1,572 & -74.4 & -4.5 \\
\hline Jiangsu & 4,604 & 4,448 & 0.19 & 5,483 & 5,298 & -185.4 & -3.4 \\
\hline Henan & 7,033 & 6,806 & 0.27 & 8,955 & 8,666 & -289.3 & -3.2 \\
\hline Shanxi & 3,761 & 3,645 & 0.63 & 6,139 & 5,950 & -189.2 & -3.1 \\
\hline Anhui & 4,422 & 4,291 & 0.38 & 6,106 & 5,925 & -180.7 & -3.0 \\
\hline Sichuan & 6,367 & 6,190 & 0.75 & 11,141 & 10,831 & -310.4 & -2.8 \\
\hline Hunan & 3,342 & 3,250 & 0.49 & 4,988 & 4,850 & -137.8 & -2.8 \\
\hline Jiangxi & 2,369 & 2,308 & 0.17 & 2,761 & 2,690 & -70.6 & -2.6 \\
\hline Guizhou & 1,873 & 1,840 & 1.62 & 4,906 & 4,820 & -86.4 & -1.8 \\
\hline Hebei & 6,603 & 6.517 & 0.14 & 7,511 & 7,414 & -97.5 & -1.3 \\
\hline Jilin & 3,999 & 3,953 & 0.34 & 5,362 & 5,301 & -61.4 & -1.1 \\
\hline Xizang (Tibet) & 224 & 222 & 0.70 & 381 & 378 & -3.2 & -0.8 \\
\hline Gansu & 3,491 & 3,483 & 0.68 & 5,880 & 5,866 & -14.3 & -0.2 \\
\hline Heilongjiang & 8,930 & 8,995 & 0.27 & 11,360 & 11,443 & 83.1 & 0.7 \\
\hline Xinjiang & 3,083 & 3,128 & 0.32 & 4,063 & 4,123 & 59.7 & 1.5 \\
\hline Ningxia & 795 & 807 & 1.31 & 1,836 & 1,864 & 28.2 & 1.5 \\
\hline Guangxi & 2,563 & 2,614 & 0.69 & 4,344 & 4,431 & 86.8 & 2.0 \\
\hline Yunnan & 2,777 & 2,871 & 1.08 & 5,788 & 5,983 & 195.1 & 3.4 \\
\hline Qinghai & 538 & 590 & 0.64 & 883 & 968 & 85.2 & 9.6 \\
\hline \multicolumn{8}{|l|}{ Inner } \\
\hline Mongolia & 4,930 & 5.491 & 0.39 & 6,834 & 7,612 & 778.2 & 11.4 \\
\hline Total & 96,821 & 94,971 & 0.44 & 139,689 & 137,103 & $-2,586.2$ & -1.9 \\
\hline
\end{tabular}

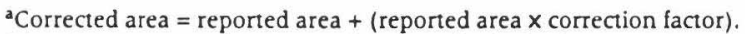

SOURCE: Wang et al. 1992; Statistical Yearbook of China 1986 (from: Crook 1993); Statistical Yearbook of China $1996: 355$

expansion of horticulture by almost 600 percent since 1949. This huge increase reflects the small absolute size of the horticulture area in 1949.

China's State Statistical Bureau has published land-use data by province. Unfortunately, they also have the problem of underreporting cultivated 
land. I used land survey data for 1985 reported by Wang and Crook to correct both the 1985 and 1995 cultivated land figures from the Statistical Yearbook of China (Wang et al. 1992; Crook 1993). As displayed in Table 3, the revised aggregated figures for total cultivated land, based on province-level data, are 139.7 and 137.1 million hectares for 1985 and 1995, respectively. As can be seen from the correction factor, underreporting was especially serious in the provinces of Guizhou (where the cultivated area according to Wang et al. was more than twice as large as reported in the Statistical Yearbooks), Ningxia, Yunnan, and Guangdong/Heinan.

Based on these revised figures I have calculated both absolute and percentage changes of cultivated land by province. I assumed that the regional pattern of underreporting remained constant between 1985 and 1995. The results indicate a decline of cultivated areas in all but seven provinces; the percent declines are most notable in Shanghai, Guangdong, and Zhejiang. Total cultivated land (based on corrected province-level data) declined by about 2.6 million hectares or 1.9 percent. This decline is significantly smaller than previous estimates (such as given in Brown 1995).

\section{Problems with China's land-use statistics}

Obviously, there are inconsistencies in the data reported above. Estimates for forest and grassland, for instance, vary considerably. The biggest problem, however, is the underreporting of cultivated areas. Both the 1993 and 1994 Statistical Yearbook of China have acknowledged that published figures for cultivated areas are "underestimated and must be further verified" (1994: 329). In 1994 China's State Land Administration (SLA) and the State Science and Technology Commission (in collaboration with UNDP and FAO) conducted a major study on land resources, use, and productivity. In a draft version of its main report, the SLA estimates that China's cultivated land area was 125.23 million hectares in the early 1990s (see UNDP et al. 1994: 38). This estimate is supported by Alexandratos (1996) from FAO in a recently published paper.

The International Institute for Applied Systems Analysis (IIASA) is conducting a project on land-use change ${ }^{1}$ in collaboration with the Chinese Academy of Sciences in which county-level data on agricultural land use are analyzed. Aggregation of these county data produces an estimated cultivated land area of about 135 million hectares. Recently, China's State Land Administration seems to have increased its previous estimate of cultivated land. According to personal communication from Harry van Velthuzen (a consultant to the SLA), the Administration is about to publish a report in which it will raise China's cropland estimate to over 134 million hectares (plus 6.7 million hectares of perennial crops, such as orchards). Finally, my own province-based estimates, shown in Table 3, resulted in a 
total cultivated area of 137.1 million hectares in 1995 (as compared to the 95 million hectares reported in the Statistical Yearbook).

In short, we now have three estimates (or, rather, ranges of estimates) of China's cultivated land area in 1992-95, not including orchards:

-the official data from the Statistical Yearbook of 95 million hectares (which is commonly considered too low);

-the widely published "corrected" estimates of about 125 million hectares (Ke 1996; Alexandratos 1996; UNDP et al. 1994); and

- the most recent revised estimates of about 135 to 137 million hectares (Wu and Guo 1994, and my own estimates in Table 3).

Thus, in the worst case we have a discrepancy of 42 million hectares, which is more than twice the total arable land of France (a major European agricultural producer); the more likely estimates of 125 and 137 million hectares are still 12 million apart-a figure comparable in size to the total arable land of Germany.

This range of uncertainty is daunting. It has serious consequences for assessing China's food prospects. Brown's (1995) widely discussed projection of China's food security, for instance, does not reflect the well-known problem of cropland underreporting-leading him to overestimate current yields and, consequently, to make extremely pessimistic assumptions about the potential for agricultural modernization. Other authors have used cropland estimates similar to the revisions noted above, leading them to more optimistic projections of China's food production capacity (Alexandratos 1996; Huang, Rozelle, and Rosegrant 1995; Islam 1995; Johnson 1994; Paarlberg 1996; Smil 1995).

The range in uncertainty will be reduced only if reliable data become available, such as from the extensive land survey (comparable to an agricultural census) that was conducted between 1990 and 1992 by the State Land Administration. Unfortunately, the results of that survey have not yet been published. All recently published estimates cited above are based on an earlier agricultural survey conducted by the State Land Administration in the mid-1980s. It is unclear whether-and especially how-these data were updated to reflect the situation in the mid-1990s.

A second problem with land-use statistics in China (as in many other parts of the world) is that their attention is heavily biased toward the agricultural sector. While one can now easily find information on cultivated areas in China's Statistical Yearbook and other sources (even if of doubtful validity), few detailed data are published on land areas used for settlements, industrial sites, or infrastructure. This deficit of information on urban and industrial land use is critical, since these are the sectors where land-use changes, recent and prospective, are likely to be most substantial.

Finally, some of the most intense land-use changes in China have occurred only during the past few years, whereas available statistical time 
series usually end in 1992 or 1993. Even results of the land survey of China from 1990 to 1992, when they become available, will not reflect the most recent changes. Areas used for urban and industrial purposes as well as for infrastructure significantly expanded after 1990.

\section{Definitions: Land-use change versus land-cover change}

Land-use change-as distinct from land-cover change-is usually an intentional human activity. People use land because they want to extract "resources" (in the widest sense) from the land in order to satisfy their needs for food, water, habitation, energy, mobility, or recreation. Humans also use land to satisfy aesthetic and spiritual ends or political and military ambitions. Land-use activities usually modify the land cover, but sometimes people also reserve land for parks where they try to minimize human interference so that a nearly "natural" land cover can remain or redevelop. No matter which type of land use we want to study, the analysis focuses on human actions and intentions, because they are the main factors that change the land cover. And these factors in turn are determined by demographic, economic, political, and social processes. To restrict a study of land-use change to an inventory or biogeophysical model of land-cover changes would be to focus on the results of the process instead of its causes (Heilig 1994).

There is, of course, land cover in China that is changed by biochemical and biophysical processes without significant and direct human intervention, such as land that is altered by seismic activities, hydrological processes, or climate change. Natural land can also be changed on a large scale by forest and grassland fires or epidemic plant diseases. Large parts of China are sparsely populated and partly covered by (almost) natural vegetation. Direct human intervention in these areas is so minimal that we can probably analyze and model the vegetation cover in a purely biogeophysical cause-and-effect framework. This, however, is not possible with China's densely populated and cultivated eastern provinces, where most of the land cover is a product of generations of human intervention. This land is not just affected but transformed by human action.

It should also be noted that even where natural land cover exists in China, human activities indirectly affect the biogeophysical process through which the land cover changes. The possible shift of vegetation belts, the migration of plant species, or the land-cover effects of hydrological changes can be linked to global climate change, which is at least partly caused by human activities. Forest and grassland fires are often manmade, and hydrological changes in remote natural areas, such as drying out of rivers, can be caused by excessive water consumption in distant agricultural, industrial, or urban areas. 


\section{Anthropogenic factors in land-use change}

The following discussion is based on the assumption that future land-use change in China's eastern provinces will be largely determined by five factors:

- the continuing increase of population,

-rural-to-urban migration and the emergence of urban agglomerates,

-accelerating economic modernization and industrialization,

-changes in diets and lifestyles among consumers, and

-changing economic and political arrangements and institutions.

\section{Further population increase}

Two characteristics of the Chinese population are significant when analyzing land-use changes: the rapid increase in numbers, especially during the past four-and-a-half decades, and the extremely uneven spatial distribution.

For more than 1,400 years-during the Han, Sui, Tang, Song, Yuan, and Ming dynasties-the Chinese empires had a population that fluctuated between 37 and 60 million (Ho 1959). Periods of growth, such as during the last half of the eleventh century (Song dynasty), were reversed by subsequent population decline (Ge 1993). The first period of sustained population growth in China was recorded between 1749 and 1851, when the population more than doubled, from about 177 to some 430 million. The increasing food demand made it necessary to expand the cropland by a factor of more than four and to improve irrigation. Also, new food crops and high-yield rice varieties were introduced (Banister 1987). This growth, however, was followed by a century of relative population stagnation due to the decline and collapse of the dynastic system, the Japanese invasion, and the outbreak of civil war (see Figure 1).

In the early seventeenth century, China and Europe had broadly similar population sizes: in 1650 China had a population of about 89 million, while Europe's population was about 103 million (see Figure 2). During the ensuing 200 years, population growth in China was more rapid than that in Europe so that in the middle of the nineteenth century China's population size exceeded Europe's by more than 150 million. A century later, in 1950, China and Europe had, again, nearly the same population: 555 million and 549 million. But then a major divergence of trends occurred. While China's population more than doubled since 1950, Europe's population increased more slowly, to 727 million. The most dramatic contrast, however, is expected to emerge during the next few decades: by 2050 China will likely have about 1.5 billion inhabitants, while Europe's population size will probably decline to well below 700 million. Thus, within only one century, China's population will have almost tripled. There are even higher, yet not implausible projections. Lutz and colleagues have es- 
FIGURE 1 China's population, AD 1-2050

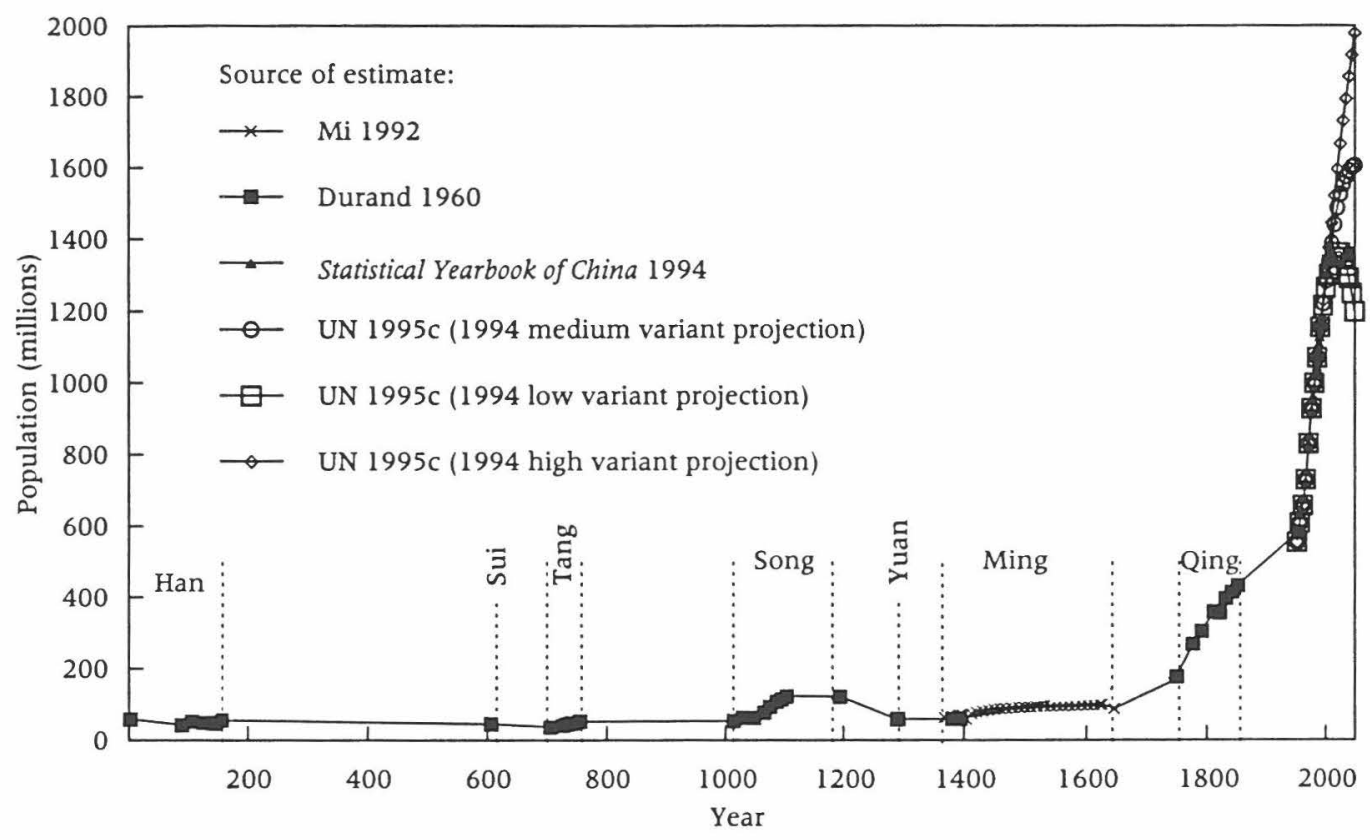

NOTE: Only the data points represent empirical estimates (or projections); the lines were added for visual convenience. The dotted lines do not represent the dynastic periods, but indicate during which dynasties the data were collected.

timated that China's population could increase to 1.9 billion by 2030 (Lutz, Prinz, and Langgassner 1994). The International Programs Center of the US Bureau of the Census, on the other hand, has estimated that China's population is likely to increase to only 1.4 billion by 2050 (Johnson 1995).

Recent evidence, reported by Feeney and others, indicates that average Chinese fertility may already have fallen below replacement level during the early 1990s (Feeney and Yuan 1994; Feeney and Wang 1993). Thus there is little scope for a further fertility decline, which would be the only option to halt China's population growth at a level below 1.4 billion. Neither massive increase of mortality nor large-scale outmigration is plausible. There is even some potential for an increase in fertility if the government relaxes the one-child policy due to widespread frustration with the measure. Taking this into account, I consider the most recent UN projection of 1.52 billion (medium variant, 1996 assessment including Taiwan but excluding Hong Kong) the most plausible (United Nations 1996). This projection seems also to be accepted by most Chinese demographers and politicians (see State Science and Technology Commission 1995).

The second salient characteristic of China's demographic situation is the concentration of its large population into the eastern part of the coun- 
FIGURE 2 Population of China and Europe, 1650, 1749, 1851, 1950, 1995,2050

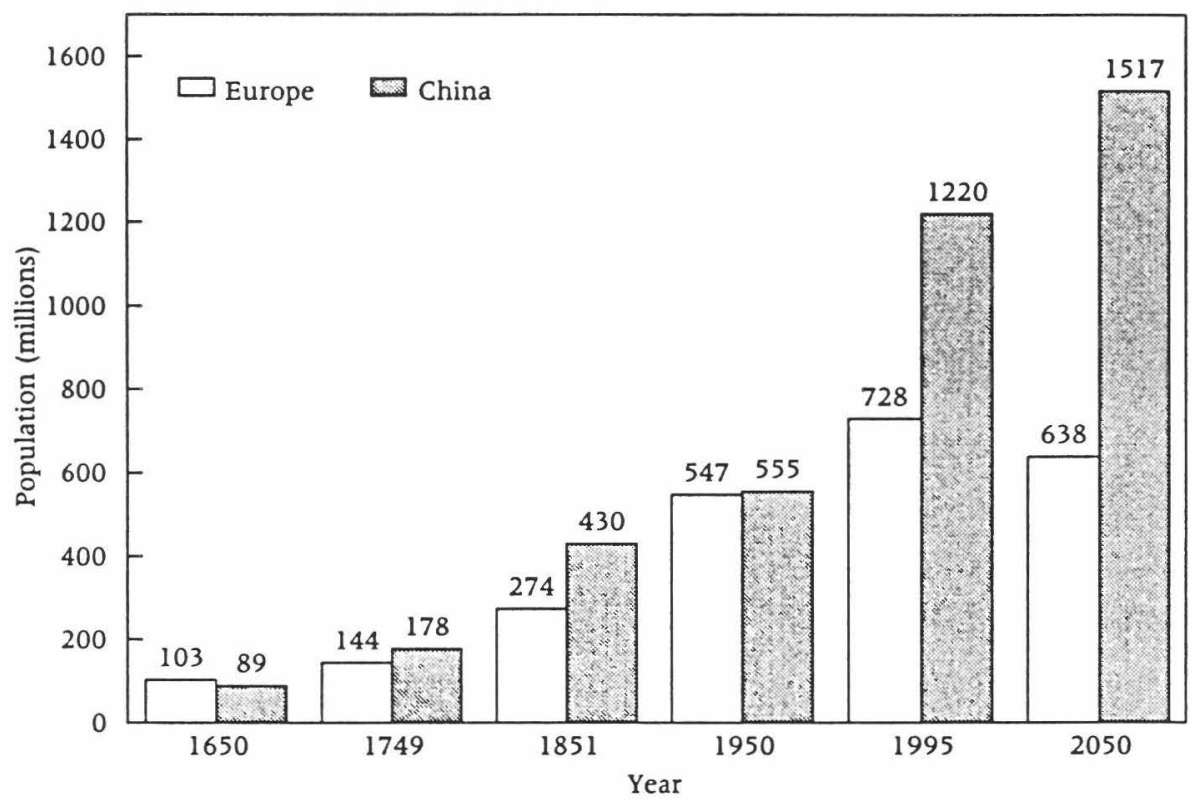

NOTE: For 1650,1749, and 1851 Europe is defined as the area west of the Urals. For 1950, 1995, and 2050 population data are from the 1996 UN projection, which, in addition to Europe as geographically defined, includes the Asian territory of the Russian Federation. The UN data for China include the Republic of Taiwan. SOURCES: Braudel (1990): 34; United Nations (1996).

try, especially the coastal zones. Much of China's land is virtually uninhabited: the Gobi Desert, the steep slopes of the Himalayas, and the vast dry grasslands of the north-central region.

I have used population and area data for 2,550 counties, cities, and city districts from China's Ministry of Public Security to analyze the spatial distribution of the Chinese population in 1992. First, I calculated the densities of all spatial units and sorted them in decreasing order. Then I cumulated both the land areas and the population. Table 4 presents the results, which should be read as follows:

-Nearly 115 million people (or 10 percent of the population) live in an area of only $47,000 \mathrm{~km}^{2}$. This is just 0.5 percent of the total land mass of China. The average population density in these most densely populated counties and cities is 2,428 persons per $\mathrm{km}^{2}$.

-Fifty percent of the Chinese population live in an area of 778,000 $\mathrm{km}^{2}$, which represents only about 8.2 percent of the total land. These areas have an average population density of 740 persons per $\mathrm{km}^{2}$.

-Roughly one billion Chinese (or more than 90 percent of the population) live in only a little more than 30 percent of the country's land area. The population density of this area is 354 persons per $\mathrm{km}^{2}$. 
TABLE 4 Cumulative distribution of China's land area and population density based on data for 2,550 counties, cities, and city districts, 1992

\begin{tabular}{rcccc}
\hline $\begin{array}{l}\text { Cumulative } \\
\text { land area } \\
\left.\mathbf{( k m}^{2}\right)\end{array}$ & $\begin{array}{l}\text { Cumulative } \\
\text { population } \\
\mathbf{1 9 9 2}(\mathbf{1 0 0 0})\end{array}$ & $\begin{array}{l}\text { Cumulative } \\
\text { percent of } \\
\text { land }\end{array}$ & $\begin{array}{l}\text { Cumulative } \\
\text { percent of } \\
\text { population }\end{array}$ & $\begin{array}{l}\text { Average pop- } \\
\text { lation density } \\
\text { (person/km })\end{array}$ \\
\hline 47,297 & 114,837 & 0.5 & 10 & 2,428 \\
170,445 & 230,247 & 1.8 & 20 & 1,351 \\
336,812 & 346,163 & 3.5 & 30 & 1,028 \\
534,411 & 460,545 & 5.6 & 40 & 862 \\
778,021 & 576,063 & 8.2 & 50 & 740 \\
$1,078,453$ & 691,192 & 11.3 & 60 & 641 \\
$1,486,455$ & 806,126 & 15.6 & 70 & 542 \\
$2,070,090$ & 921,771 & 21.7 & 80 & 445 \\
$2,927,574$ & $1,036,728$ & 30.7 & 90 & 354 \\
$9,543,280$ & $1,152,355$ & 100.0 & 100 & 121 \\
\hline
\end{tabular}

NOTE: Due to missing data in some counties and city districts, the cumulative land area reported here is less than the total land area of China.

SOURCE: People's Republic of China (1993)

In short, most of the population of China is concentrated in less than one-third of the country, where the average population density is greater than that of Belgium.

The map in Figure 3 also illustrates the spatial concentration of the Chinese population. It shows those Chinese counties, cities, and city districts that have a density of more than 150 persons per $\mathrm{km}^{2}$ (gray and black areas). The Yangtze Delta, Sichuan, and the counties and cities along the eastern coast are the main centers of population. On the other hand, 50 percent of the Chinese land mass is very sparsely populated, with a density ranging between 2 persons per $\mathrm{km}^{2}$ in Tibet to 19 persons per $\mathrm{km}^{2}$ in Inner Mongolia. Only 3.6 percent of the country's population live in these vast areas.

The highly uneven population distribution of China reflects not only the concentration of arable land in the east, but also the transportation problems of a continental-scale country. Chinese civilization spread along the coastal zones and main rivers, using sea and river transport as a backbone of expansion.

China has not only the largest population of any country, but also large subnational populations of very high density. To give a sense of the specific combination of population size and density, Table 5 compares Chinese provinces with industrialized countries (or regions) of similar population size. The Chinese provinces are typically much more densely populated than their counterparts elsewhere. 
FIGURE 3 Population distribution of China, 1992

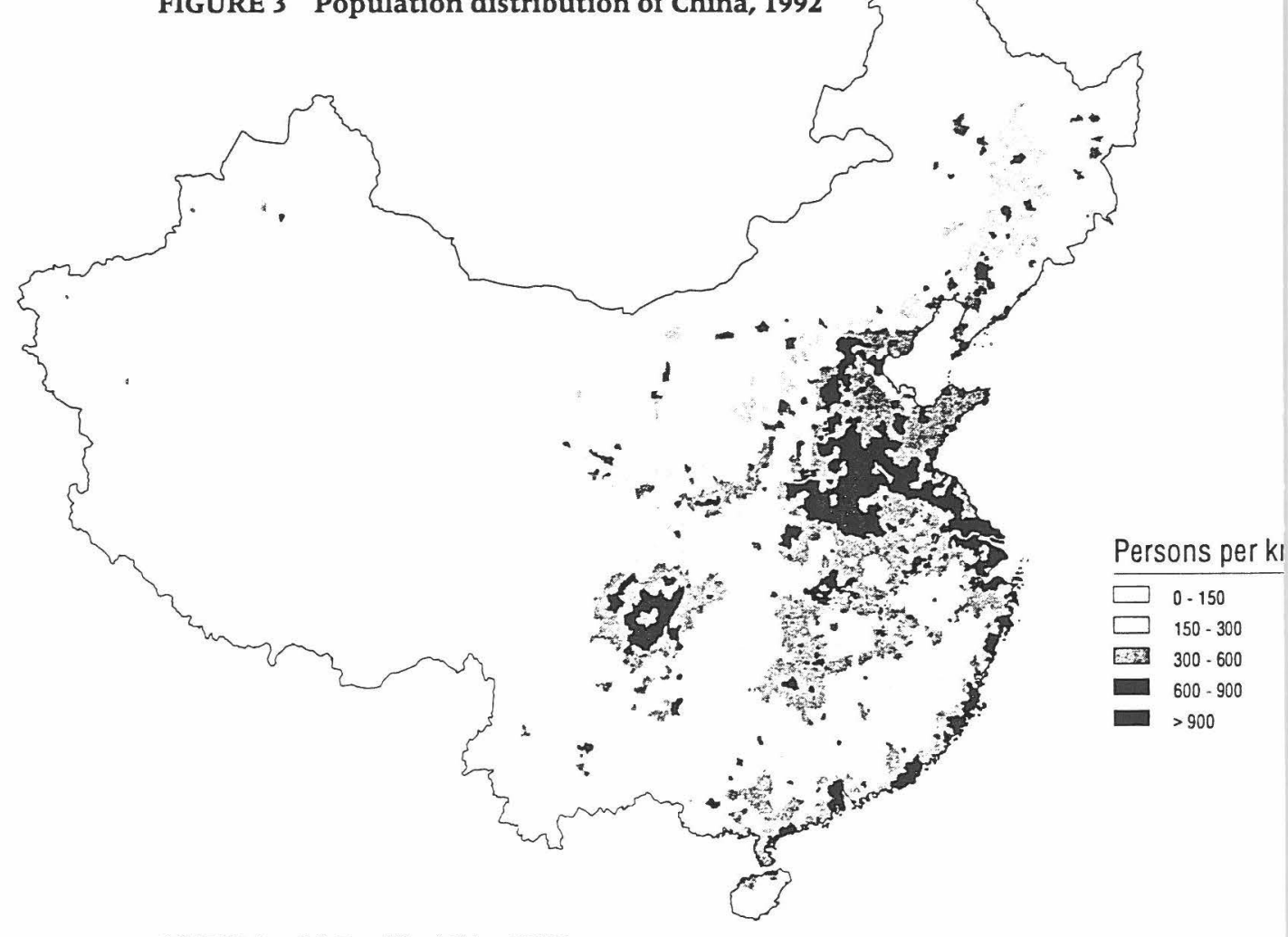

SOURCE: People's Republic of China (1993)

The Chinese province of Anhui, for instance, has the same population size as Italy, but more than twice the density, 420 as compared to 189 person per $\mathrm{km}^{2}$. Spain has a population of 39 million, as does the Chinese province of Liaoning; but Spain's population density is 78 persons per $\mathrm{km}^{2}$ while Liaoning's is 273 . Densely settled Germany had a population of about 80 million in 1990-somewhat more than Guangdong (combined with Hainan). These Chinese provinces, however, have a much higher population density of 343 persons per $\mathrm{km}^{2}$ as compared to 222 in Germany. All countries of Middle Africa combined have about the same population as the Chinese province of Jiangsu; the average population density in Middle Africa, however, is 11 as compared to 663 persons per $\mathrm{km}^{2}$ in Jiangsu. As a last example, both Mexico and the Chinese province of Shandong have a population of some 85 million inhabitants; the Chinese province, however, has a population density 13 times higher than that of Mexico. The extremely high density of China's very large (and still mostly rural) population is a critical factor in the country's future development. 
TABLE 5 Population density of selected Chinese provinces and of selected countries or regions with comparable population size

\begin{tabular}{|c|c|c|c|c|c|}
\hline \multicolumn{3}{|l|}{ Chinese provinces } & \multicolumn{3}{|c|}{ Other countries/regions } \\
\hline & $\begin{array}{l}\text { Total } \\
\text { population } \\
1993 \\
\text { (millions) }\end{array}$ & $\begin{array}{l}\text { Population } \\
\text { density } \\
\text { (persons } / \mathbf{k m}^{2} \text { ) }\end{array}$ & & $\begin{array}{l}\text { Total } \\
\text { population } \\
1990 \\
\text { (millions) }\end{array}$ & $\begin{array}{l}\text { Population } \\
\text { density } \\
\text { (persons } / \mathbf{k m}^{2} \text { ) }\end{array}$ \\
\hline Shandong & 86.2 & 562 & Mexico & 84.5 & 43 \\
\hline Guangdong/Hainan & 72.6 & 343 & Germany & 79.4 & 222 \\
\hline Jiangsu & 68.0 & 663 & Middle Africa ${ }^{a}$ & 70.5 & 11 \\
\hline Hunan & 62.5 & 306 & Iran & 58.9 & 36 \\
\hline Anhui & 58.7 & 420 & Italy & 57.0 & 189 \\
\hline Hubei & 55.9 & 301 & France & 56.7 & 103 \\
\hline Liaoning & 39.8 & 273 & Spain & 39.3 & 78 \\
\hline Shanxi & 29.6 & 189 & Canada & 27.8 & 3 \\
\hline Inner Mongolia & 22.0 & 19 & Australia & 16.9 & 2 \\
\hline Tianjin & 8.9 & 787 & Sweden & 8.6 & 19 \\
\hline Ningxia & 4.9 & 95 & Finland & 5.0 & 15 \\
\hline
\end{tabular}

aPopulation of Angola, Cameroon, Central African Republic, Chad, Congo, Equatorial Guinea, Gabon, and Zaire combined. SOURCES: Statistical Yearbook of China (1994): United Nations (1995c).

Within the next five decades China will have to provide food, energy, employment, resources, and housing to roughly an additional 300 million people. These new people will need additional space for housing and urban infrastructure, predominantly in the eastern part of the country and its coastal zones, where space can often be taken only from cultivated areas. This competition in land-use activities is a core problem of China's-and the world's-food security (Heilig 1996).

\section{Urbanization}

China has long been the prototype of a rural society. After 1949, the government's closed-city policy effectively prevented rapid urbanization, and 72 percent of the population is still classified as rural (Statistical Yearbook of China 1994). There are numerous methodological problems in the classification and projection of urban populations in China (Goldstein 1990; Ma and Cui 1987; Ma and Lin 1993), but the general trend is clear. Attracted by the rapidly growing manufacturing and service sectors in towns and urban areas, and pushed by rural unemployment, millions of Chinese peasants will become urban dwellers in the near future. According to Chinese sources, the number of settlements classified as cities is projected to almost double within the next 15 years, from a current 570 to about 1,000. 
The United Nations Population Division is monitoring the population of China's 51 largest cities and urban agglomerations (United Nations 1995a). According to their estimates, which are based on Chinese reports, these cities had a total population of about 39 million in 1950. Today, their population is about 134 million. The UN recently projected that within 20 years their combined population would further increase to about 220 million. As shown in Figure 4, for instance, Shanghai's population is projected to increase to 23 million by 2015, mainly due to rural-to-urban migration; Beijing's is expected to reach 19 million and Tianjin's nearly 17 million (United Nations 1995a). These projections appear fairly conservative, by comparison to historical trends. Between 1950 and 1995 China's largest city populations had an average annual growth rate of 2.8 percent. The UN projections imply that this growth will slow to an annual rate of 2.0 percent between 1995 and 2015.

The State Statistical Bureau has estimated that the urban population of China will increase from 28 percent of the total population in 1995 to 50 percent in 2010. In its most recent assessment the United Nations Population Division has estimated an urban population of one billion in 2050-

FIGURE 4 Estimated and projected population of selected Chinese cities, 1950-2015

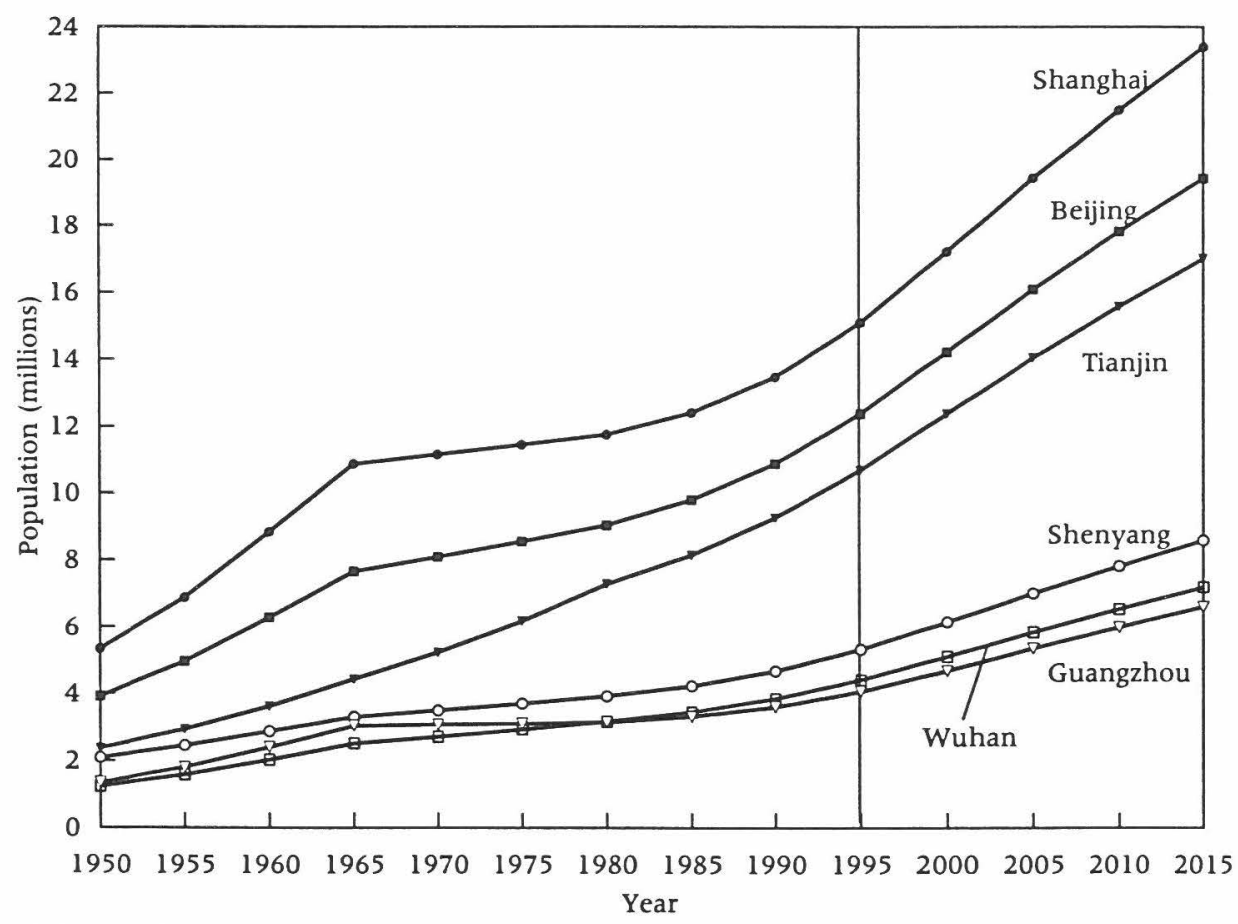

SOURCE: United Nations (1995a). 
two-thirds of the total population projected for that year. In 1950 China's urban population was estimated at 61 million (United Nations 1995b). This 940 million increase in the number of city dwellers is bound to be paralleled by a major, although less than proportional, expansion of urban land use.

The growth of China's cities and urban agglomerations depends, of course, on future political and economic conditions. In the 1970s and 1980s, the government sought to restrict the number of rural-urban migrants. However, there are good economic reasons to believe that even if China's government tries to maintain restrictions on spatial mobility, massive rural-urban migration and city growth cannot be stopped. Beijing and Shanghai already have so-called floating populations of between 1 and 2 million each. Powerful pull and push factors will generate-if necessary, illegalrural-to-urban migration.

First, there is a huge demand for low-wage rural labor in China's cities and other urban areas, due to rapid industrialization. Many construction companies already hire their unskilled workers directly from rural areas. The booming towns and cities also offer numerous opportunities for starting a small private business-from selling self-made household items to running a food stall or a street restaurant. Jobs and business opportunities, however, are not the only attractions of towns and cities. Cities provide better facilities for education, health care, and entertainment than the villages. Only strict control of mobility has so far prevented many of the young and energetic from migrating to urban areas. Without these controls a tidal wave of migrants would seek out urban opportunities.

Second, the large reservoir of the rural unemployed is likely to increase significantly in the next decades. As I noted above, between 1995 and 2050 China's population is expected to grow by about 300 million. Most of this growth will originate in rural areas, but it is unlikely that it can be fully absorbed there. Rural unemployment already exists, and the mechanization and modernization of agriculture will further reduce labor demand. Since 1978, agricultural machinery (tractors) available to farmers has increased by a factor of ten; nitrogen fertilizer input grew twelvefold. The size of the agricultural labor force will probably stagnate or even decline, as China moves further toward modern agricultural production methods (Rempel 1996). Population growth and stagnating agricultural labor demand will probably generate a large excess rural population. According to official Chinese estimates the country may have some 100 million idle farmers (Li 1994: 168-169). Other Chinese experts estimate that the surplus of rural labor is on the order of 150 million and could increase to 190 million by the year 2000 (Jiang, Feldman, and Zhang 1995).

The growth of cities and towns usually leads to a conversion of arable land into built-up areas, although increasing population density (e.g., "vertical growth" by means of high-rise buildings) somewhat moderates this 
effect. In contrast to agricultural land-use changes, which are usually reversible, transformation of arable land into built-up areas, such as highways or settlements, tends to be permanent or reversible only at very high costs. Table 6 reports increases in built-up land in 12 major urban areas of China in which such expansion was especially pronounced, either in absolute or in proportional terms, between 1989 and 1995.

Of course, not all land in urban areas is sealed off by houses or roads. Often a significant portion of urban land looks "natural," such as parks, gardens, or vegetation belts between highway lanes. It is not the appearance of land, however, but the purpose of its use, that determines how it is classified. The purpose of agricultural land is the production of food and other agricultural products; it serves the agricultural population as a source of food and income. Urban land, on the other hand, no matter how "green" it appears, provides space for housing, consumption, spatial mobility, recreation, education, and entertainment to people who earn their income in nonagricultural activities.

Urbanization not only causes an expansion of built-up areas but also has far-reaching indirect effects on land-use change. City dwellers need a much broader supply and service infrastructure than rural populations, from shopping centers to water reservoirs. They usually cannot build their houses with local products, such as clay or wood; instead, steel mills and cement

TABLE 6 Increase of built-up land in 12 urban areas of China between 1989 and 1995 (sorted by population size in 1995)

\begin{tabular}{|c|c|c|c|c|c|c|c|c|}
\hline \multirow[b]{2}{*}{ City } & \multicolumn{2}{|c|}{$\begin{array}{l}\text { Population } \\
\text { (millions) }\end{array}$} & \multicolumn{2}{|l|}{$\begin{array}{l}\text { Population } \\
\text { increase } \\
1989-95\end{array}$} & \multicolumn{2}{|c|}{$\begin{array}{l}\text { Urban } \\
\text { built-up } \\
\text { area }\left(\mathrm{km}^{2}\right)\end{array}$} & \multicolumn{2}{|c|}{$\begin{array}{l}\text { Increase in } \\
\text { built-up area } \\
1989-95\end{array}$} \\
\hline & 1989 & 1995 & (millions) & (percent) & 1989 & 1995 & $\left(\mathrm{~km}^{2}\right)$ & (percent) \\
\hline Chongqing & 3.0 & 15.2 & 12.2 & 413.7 & 84 & 184 & 100 & 118.8 \\
\hline Shanghai & 7.8 & 13.0 & 5.2 & 67.3 & 248 & 390 & 142 & 57.1 \\
\hline Beijing & 6.2 & 10.7 & 4.5 & 73.3 & 395 & 477 & 82 & 20.6 \\
\hline Chengdu & 2.8 & 9.7 & 6.9 & 250.1 & 83 & 129 & 46 & 55.0 \\
\hline Shijiazhuang & 1.2 & 8.5 & 7.3 & 615.7 & 69 & 97 & 28 & 40.8 \\
\hline Guangzhou & 3.5 & 6.5 & 2.9 & 83.3 & 182 & 259 & 77 & 42.1 \\
\hline Hangzhou & 1.3 & 6.0 & 4.7 & 350.3 & 68 & 102 & 34 & 50.5 \\
\hline Fuzhou & 1.3 & 5.6 & 4.4 & 342.9 & 49 & 68 & 19 & 38.7 \\
\hline Dalian & 2.4 & 5.4 & 3.0 & 125.8 & 101 & 218 & 117 & 115.8 \\
\hline Hefei & 1.0 & 4.1 & 3.1 & 320.7 & 66 & 86 & 20 & 29.9 \\
\hline Hohhot & 0.9 & 1.8 & 0.9 & 104.1 & 58 & 78 & 20 & 35.5 \\
\hline Urumqi & 1.1 & 1.4 & 0.3 & 29.6 & 62 & 83 & 21 & 32.9 \\
\hline
\end{tabular}

NOTE: Population figures are based on city infrastructure statistics and are different from population figures of the Ministry for Public Security or those shown in Figure 4 above.

SOURCE: Statistical Yearbook of China 1990 and 1996: 332, 335, 632. 
factories are necessary for urban construction. They cannot collect firewood for cooking and heating, but depend on the production and distribution of commercial energy. Cities also need special areas for sewage treatment and waste disposal. In a village this is often done by reserving a certain spot behind the house. The process of urbanization usually triggers the growth of specific commercial sectors, supply infrastructures, and city-specific land-use forms, such as parks, recreation areas, and sport stadiums.

\section{Economic modernization and industrialization}

The economic reforms of 1978 were probably more important to China's future land-use patterns than any other single event in recent history (Yabuki 1995). A decade after the dislocations of the Cultural Revolution and two years after Mao Zedong's death, China's leaders decided to gradually abandon the system of collective land ownership and centralized command economy. Family farming was reintroduced along with a limited system of agricultural markets. The impact was spectacular. Agricultural output increased rapidly and at rates well exceeding the rate of population growth. Within ten years, China's peasants almost doubled the production of rice. But the growth was not only in volume; decentralized planning favored diversification, and farmers began to concentrate on products in which they had a comparative advantage. Before the liberalization, central planners had often forced them to grow rice where it would have been more economical to grow wheat, or to keep pigs where they could have been raising cattle. The new flexibility broadened the range of agricultural production to non-rice crops, aquacultures, and various livestock. Consumption of meat, a scarce food item in the 1950s and 1960s, began to soar. Available statistics indicate the great expansion and increasing diversity of agricultural production after 1978 (see Figure 5).

The growth of agricultural production from 1978 to the mid-1980s was far more rapid than most observers anticipated. It was driven, as Barnett (1986: 7-8) noted, by the "deep-rooted entrepreneurial impulses among China's peasants that long have been suppressed." The spurt in agricultural productivity eliminated the greatest risk for the Chinese peasant: famine. Less than a generation after some 30 million people had died in the famine of the Great Leap Forward (Ashton et al. 1984), farmers could not only feed their families, but also increase their consumption of meat, fish, sugar, and fruits. For the first time, farmers could also generate enough money to buy such consumer goods as bicycles, televisions, and watches. National income statistics show the trigger effect of the 1978 reforms.

Chinese business acumen showed up with even greater clarity as the first wave of economic modernization in China began to subside in the mid-1980s. The economic reforms not only returned farmland to the peas- 
FIGURE 5 Indexes of per capita output (in $\mathrm{kg}$ ) of major agricultural products, $1952-93(1952=100)$

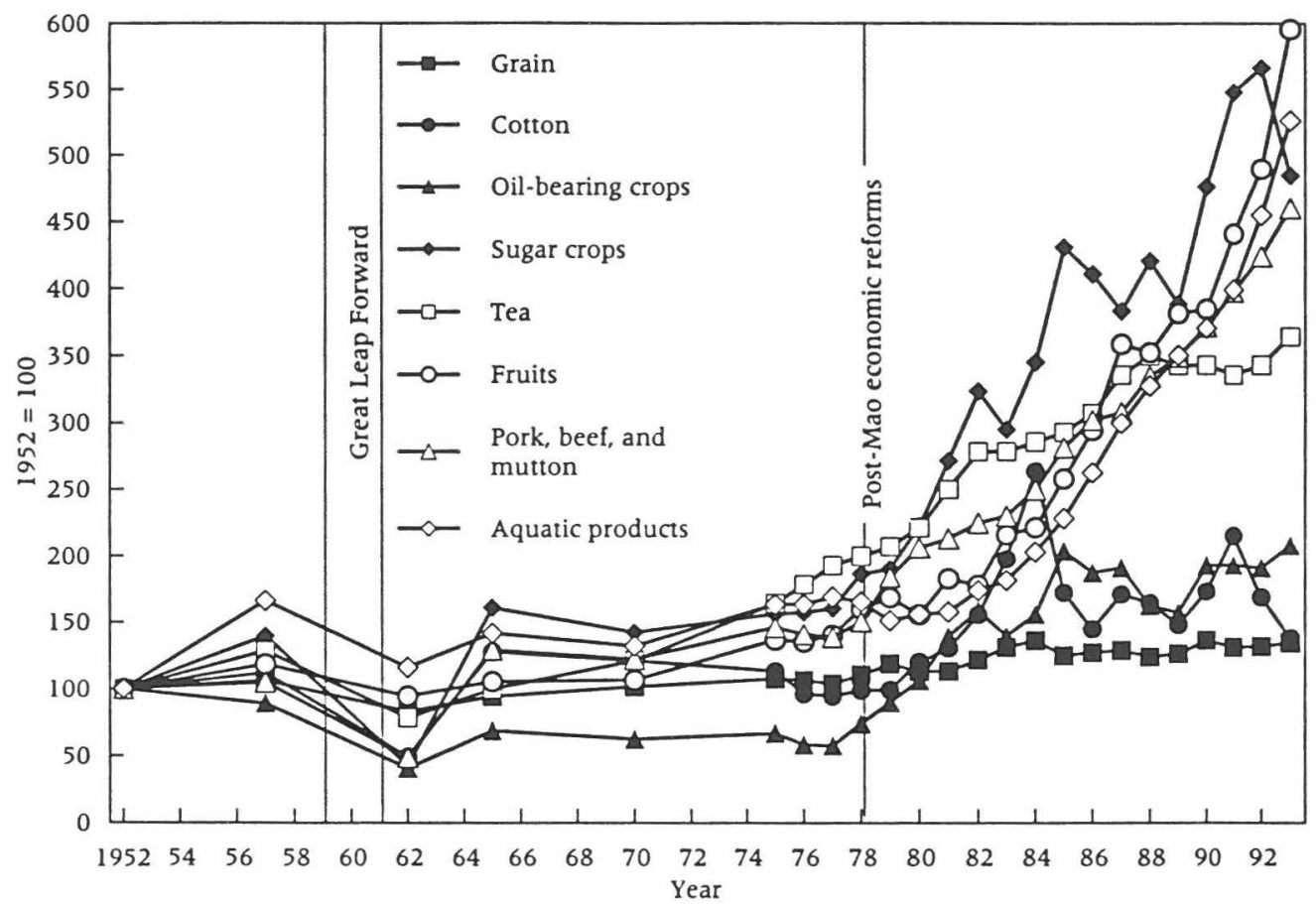

SOURCE: Statistical Yearbook of China 1994: 31

ants, but also fostered the development of small-scale rural industries. These village and township enterprises were highly successful (Baum 1994). Their number increased more than twelvefold, from 1.5 million in 1978 to 19 million in 1991, at which time they generated about 30 percent of China's gross national product-exceeding the share of agricultural output (Kristof and WuDunn 1994). In the early 1990s further Dengist reforms stimulated peasants' engagement in countryside enterprises. Between 1991 and 1993, the number of such enterprises further increased from 19 million to almost 25 million (Statistical Yearbook of China 1994: 361).

With these reforms, the Chinese leadership successfully addressed three fundamental problems of any developing economy: it reduced the power of the central bureaucracy, slowed the migration of farmers to the cities, and provided an opportunity for rural people to learn about modern technology and business. Unlike state-run heavy industries, the town and village enterprises, which typically employ only a few dozen to a few hundred people, are owned by local governments, and their management is largely independent of national plans and regulations. Decentralized plan- 
ning facilitated innovation. While most enterprises started with the production of crude consumer goods for local demand, some of them soon switched to the production of more-profitable goods for urban and international consumers. Some rural enterprises are heavy polluters of agricultural land and most are still far from Western standards of efficiency, but they have helped to absorb excess agricultural labor-corresponding to an estimated total population of 100 million to 200 million. The greatest potential benefit of rural enterprises, however, is that they generate a broad cadre of managers and skilled laborers who are familiar with market mechanisms, understand technology, and have learned the discipline of manufacturing processes.

This broad base of trained human resources is a prerequisite for success in the third phase of economic modernization in China that started in the early 1990s and is in full swing today. It is characterized by rapid growth of the industrial, transportation, and construction sectors.

The geographical center of China's economic modernization is the heavily populated coastal provinces of Guangdong, Jiangsu, Shandong, Liaoning, and Shanghai, where in 1993 the gross domestic product was nearly 90 times higher than in the western part of the country. Guangdong's GDP alone was equivalent to the combined GDP of Xinjiang, Tibet, Qinghai, Gansu, Yunnan, Inner Mongolia, and Heilongjiang provinces. In other words, on 2.2 percent of China's total land area, the province of Guangdong generates the same GDP as the seven other provinces just listed, which cover almost 63 percent of the country's land area (see also Tuan 1993). Economic observers suggest that the urban areas of the Yangtze Delta, which represent the centers of China's economic growth, will fuse into an extended metropolitan area as did the urban centers along America's east coast, from Boston through New York to Washington, D.C. (The Economist 1995).

While Western scholars speculate about a China whose transportation problems would be solved (for the sake of decreasing global carbon dioxide emissions) by a mixture of reliance on bicycles and access to public transportation, China's planners have decided that road transport will be a backbone of the country's economy (The Economist 1996). And private car ownership is envisaged as the growth engine for this plan (Tyler 1994). In late 1994, He Guangyuan, China's minister of industry, announced that "to increase car sales the state will introduce incentives to car buyers to boost market demand" (International Herald Tribune 1994). In the summer of 1995, the Chinese government declared that the automotive sector will be the "pillar industry" of the economy. In the meantime, China's automobile industry, which was fragmented into some 125 state-run car manufacturers, is in the process of consolidation. Three or four large producers are expected to emerge from joint ventures with foreign companies, doubling annual car production from today's 1.5 million to 3 million in the 
year 2000. By 2010, annual production could reach more than 4 million cars (International Herald Tribune 1995).

How will this economic transition affect the use of land in China? A number of major trends can be anticipated. Expanding facilities for energy generation (water reservoirs), transportation infrastructure, and commercial buildings will consume valuable cropland in China. To meet economic growth, Chinese researchers have estimated, energy production will have to be increased by at least three to five times. Most of this energy will come from coal, but there are also plans to expand hydropower. The construction of reservoirs will directly affect land use in river valleys. Work on the $\$ 30$ billion "Three Gorges" project, a massive scheme to dam the Yangtse River, was started only recently. This dam will drown some 46,000 hectares of fertile land (Topping 1995).

Further economic growth in China will require a massive expansion of the private transportation sector. Between 1978 and 1995, total freight traffic in China almost quintupled, from 983 to 3,573 billion $\mathrm{t} \mathrm{km}$ (see Table 7). The modernization and commercialization of agriculture and the further expansion of industry need a much larger transportation capacity than do traditional farming and small-scale industries. Farmers have to supply distant markets within (and possibly also outside) the country. They need inputs (fertilizer, pesticides) that are produced in industrial areas and must be transported to rural areas. Export-oriented industrial production, which is rapidly expanding in China, generates a much higher transportation volume than traditional small-scale industries that supplied local markets. The growth of transportation infrastructure is already well underway. Highways, such as those between Guangzhou and Shenzhen, between Beijing and Shijiazhuang, and between Beijing and Tianjin, will cut through former rice paddies to connect the industrial and urban centers in China's eastern provinces. Between 1980 and 1993 the area of paved roads in urban areas more than quintupled, from $253 \mathrm{~km}^{2}$ to $1,358 \mathrm{~km}^{2}$, and the per capita area of urban roads increased from 2.8 to $7.3 \mathrm{~m}^{2}$ (Statistical Yearbook of China 1996). And all large cities in China will expand their perimeter due to an uncurbed construction boom.

The automobile industry (which was also the growth engine of Germany's "economic miracle" in the 1950s and 1960s) is expected not only to boost China's economy, but also to transform its economic structure. Private trucks will stimulate economic flexibility and expand markets. Commercial road transport in China will accelerate the transition from an agricultural to an industrial and service economy. Small-scale producers and service enterprises will be able to reach distant markets and consumers. The automobile will also change everyday life in China. With a "people's car" (the Chinese actually use the same term as the popular German automobile, "Volkswagen") individual mobility ${ }^{2}$ will greatly increase. 
TABLE 7 Selected consumption and lifestyle-related statistics for China, 1985 and 1995, and percent increase between the two years

\begin{tabular}{|c|c|c|c|}
\hline & 1985 & 1995 & $\begin{array}{l}\text { Increase } \\
1985-95 \\
\text { (percent) }\end{array}$ \\
\hline \multicolumn{4}{|l|}{$\begin{array}{l}\text { Ownership of major durable consumer } \\
\text { goods (per } 100 \text { households) }\end{array}$} \\
\hline \multicolumn{4}{|l|}{ Urban households } \\
\hline Bicycles & 152.3 & 194.3 & 28 \\
\hline Washing machines & 48.3 & 89.0 & 84 \\
\hline Refrigerators & 6.6 & 66.2 & 906 \\
\hline Color television sets & 17.2 & 89.8 & 422 \\
\hline Recorders & 22.3 & 45.3 & 103 \\
\hline Cameras & 8.5 & 30.6 & 259 \\
\hline \multicolumn{4}{|l|}{ Rural households } \\
\hline Bicycles & 80.6 & 147.0 & 82 \\
\hline Washing machines & 1.9 & 16.9 & 789 \\
\hline Refrigerators & 0.1 & 5.2 & 8,483 \\
\hline Color television sets & 0.8 & 16.9 & 2,015 \\
\hline Recorders & 4.3 & 28.3 & 552 \\
\hline Cameras & & 1.4 & \\
\hline \multicolumn{4}{|l|}{ Mobility/transportation } \\
\hline Total passenger traffic ${ }^{\mathrm{b}}$ (billion person $\mathrm{km}$ ) & 443.7 & 900.2 & 103 \\
\hline Civil aviation & 11.7 & 68.1 & 482 \\
\hline Highways & 172.5 & 460.3 & 167 \\
\hline Railways & 241.6 & 354.6 & 47 \\
\hline Total freight traffic volume ${ }^{c}$ (billion $\mathrm{t} \mathrm{km}$ ) & $1,812.6$ & $3,573.0$ & 97 \\
\hline Civil aviation & 0.4 & 2.2 & 458 \\
\hline Highways & 169.3 & 469.5 & 177 \\
\hline Railways & 812.6 & $1,287.0$ & 58 \\
\hline Total number of tourists ${ }^{\mathrm{d}}$ (millions) & 17.8 & 46.4 & 160 \\
\hline Area of paved roads in urban areas $\left(\mathrm{km}^{2}\right)$ & 359 & 1,358 & 279 \\
\hline $\begin{array}{l}\text { Per capita area of paved roads in } \\
\text { urban areas }\left(\mathrm{m}^{2}\right)\end{array}$ & 3.1 & 7.3 & 135 \\
\hline \multicolumn{4}{|l|}{ Income, standard of living } \\
\hline \multicolumn{4}{|l|}{ Urban households } \\
\hline Annual per capita income (yuan) ${ }^{e}$ & 685 & 3,893 & 468 \\
\hline Per capita floor space $\left(\mathrm{m}^{2}\right)$ & 5.2 & 8.1 & 56 \\
\hline \multicolumn{4}{|l|}{ Rural households } \\
\hline Annual per capita income of farmers (yuan) ${ }^{f}$ & 398 & 1,578 & 297 \\
\hline Per capita floor space $\left(\mathrm{m}^{2}\right)$ & 14.7 & 21.0 & 43 \\
\hline
\end{tabular}

a Based on sample surveys of urban and rural households. b Total number of passengers $x$ transportation distance $(\mathrm{km})$. "Total freight volume (in $\mathrm{t}) \times$ transportation distance $(\mathrm{km})$. ${ }^{\mathrm{d}}$ Total number of tourists in 1995 include: 5.9 million foreign tourists and 40.5 million Chinese from Hong Kong, Macao, Taiwan, or overseas. e Disposable income after tax. 'Total income after deduction of investments (agricultural inputs, construction); this is an indicator of peasants' actual income level. SOURCES: Statistical Yearbook of China 1994: 22, 24, 312; Statistical Yearbook of China 1996: 279, 283, 309, 334, 500,579 
Changes in diets and lifestyles

Changing diets can have a large impact on agriculture. It makes a major difference in terms of land use and energy efficiency whether the bulk of one's daily calories are consumed as a T-bone steak or bowls of rice. In speculating about trends in food consumption, much depends on the future level of incomes and the pattern of prices for food and nonfood items. But cultural factors also have to be taken into account. Food consumption is not just the supply of carbohydrates, protein, fat, vitamins, and fiber. It is also a way of life (Heilig 1993). Chinese cuisine may resist Western dietary trends.

We know that urban populations consume different kinds of food than do peasants. An increase in the proportion of the population that is urban will affect China's overall food composition. Time-series data indicate that a significant change in diets has already occurred in China during the last few decades (see Figure 6). Cross-country comparisons are another way to examine future trends of food consumption in China. Other Asian countries, such as Japan and South Korea, have undergone changes in dietary patterns that help to predict the direction of the Chinese transition (see Table 8). And finally, cultural influences on Chinese food preferences, mainly coming from the West, may be more rapid and profound than expected. Several trends seem relevant in this regard.

China's meat consumption significantly increased during the past 30 years. Per capita output of animals slaughtered, for instance, grew from about $4 \mathrm{~kg}$ per year in 1961 to almost $30 \mathrm{~kg}$ per year in 1992. The increase of meat consumption in China was mainly due to increased consumption of pork. Mutton, veal, and beef are not very popular in China.

It is likely that the consumption of animal-based foods (meat, dairy products, eggs) will further increase in China. Other Asian countries, such as Japan, already consume relatively high levels of animal-based foods (see Table 8). If Hong Kong's dietary patterns are indicative of China's future food preferences, a massive increase in the consumption of animal-based food products (especially milk and meat) can be anticipated. The "Western" dietary pattern is probably most clearly represented by the United States. The US diet could be considered to represent an upper limit for the consumption of meat and dairy products.

What would be the land-use consequences of an accelerated trend toward an animal-based diet in China? A further increase of pork consumption would probably boost the demand for feed crops, such as corn and soybeans; the area devoted to soybean cultivation increased significantly during the last few years in China. While soybeans originated in China and were cultivated there nearly 5,000 years ago (Cheng 1993: 179), the crop was not extensively grown before the late 1980s. The 1994 Statistical Yearbook reports the area of cultivation for soybeans beginning with 
FIGURE 6 Food consumption patterns in China: Average daily per capita calorie consumption and percent of that consumption accounted for by various food products, 1961-94
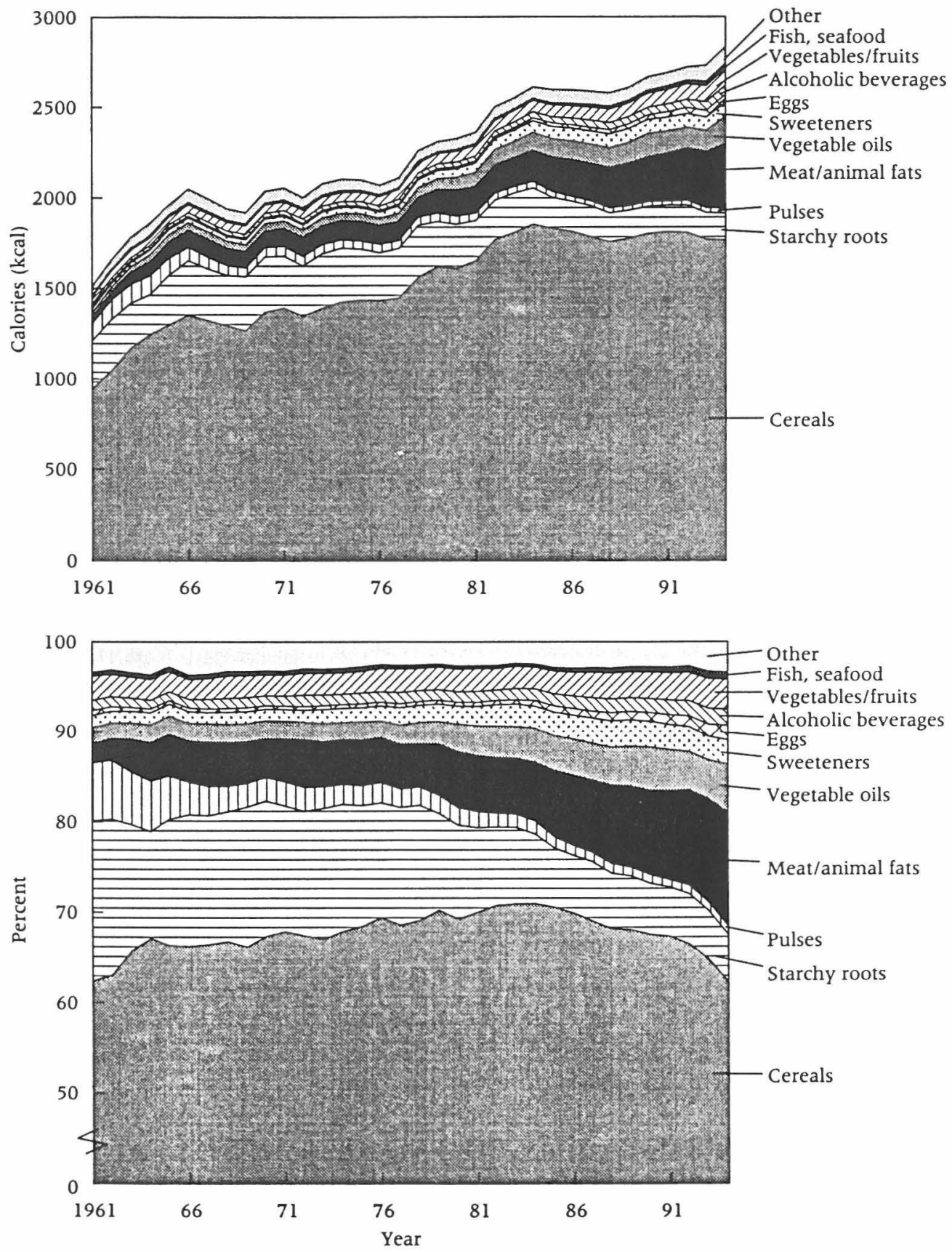

NOTE: Cereals (mainly rice and wheat) account for between 63 percent and 69 percent of the average Chinese calorie supply. Changes in the proportion of other food products are much smaller. To make these visible the vertical axis in the lower part of the figure is calibrated to highlight the change in the percentage of calorie consumption accounted for by non-cereal items. SOURCE: FAO 1996 
TABLE 8 Patterns of food consumption in China, Hong Kong, Korea, Japan, United States, and the European Union: Average calorie consumption per capita per day, 1992-94 (three-year average)

\begin{tabular}{|c|c|c|c|c|c|c|}
\hline & \multicolumn{6}{|c|}{ Calories, by source, per capita/day (kcal) } \\
\hline & China & $\begin{array}{l}\text { Hong } \\
\text { Kong }\end{array}$ & Korea & Japan & USA & $\mathrm{EU}(12)$ \\
\hline Total & 2,762 & 3,220 & 3,229 & 2,890 & 3,609 & 3,458 \\
\hline Vegetable products & 2,362 & 2,284 & 2,765 & 2,297 & 2,502 & 2,337 \\
\hline Animal products & 401 & 936 & 464 & 593 & 1,107 & 1,122 \\
\hline Cereals, excluding beer & 1,782 & 1,024 & 1,558 & 1,186 & 833 & 820 \\
\hline Meat & 286 & 521 & 238 & 153 & 442 & 481 \\
\hline Starchy roots & 147 & 61 & 33 & 74 & 102 & 149 \\
\hline Vegetable oils & 130 & 552 & 251 & 267 & 455 & 468 \\
\hline Sweeteners & 74 & 301 & 294 & 292 & 628 & 365 \\
\hline Vegetables & 61 & 53 & 148 & 75 & 66 & 80 \\
\hline Alcoholic beverages & 49 & 54 & 258 & 160 & 37 & 205 \\
\hline Eggs & 39 & 54 & 36 & 79 & 51 & 50 \\
\hline Animal fats & 31 & 119 & 46 & 49 & 202 & 221 \\
\hline Fruits & 29 & 93 & 71 & 54 & 137 & 135 \\
\hline Pulses & 27 & 27 & 36 & 21 & 35 & 33 \\
\hline Fish, seafood & 22 & 104 & 90 & 185 & 30 & 39 \\
\hline Milk & 13 & 108 & 28 & 111 & 366 & 311 \\
\hline Stimulants & 1 & 20 & 3 & 19 & 14 & 21 \\
\hline \multirow[t]{3}{*}{ Other } & 72 & 129 & 138 & 162 & 213 & 81 \\
\hline & \multicolumn{6}{|c|}{ Calories by source (percent) } \\
\hline & China & $\begin{array}{l}\text { Hong } \\
\text { Kong }\end{array}$ & Korea & Japan & USA & EU(12) \\
\hline Total & 100.0 & 100.0 & 100.0 & 100.0 & 100.0 & 100.0 \\
\hline Vegetable products & 85.5 & 70.9 & 85.6 & 79.5 & 69.3 & 67.6 \\
\hline Animal products & 14.5 & 29.1 & 14.4 & 20.5 & 30.7 & 32.4 \\
\hline Cereals, excluding beer & 64.5 & 31.8 & 48.3 & 41.1 & 23.1 & 23.7 \\
\hline Meat & 10.4 & 16.2 & 7.4 & 5.3 & 12.2 & 13.9 \\
\hline Starchy roots & 5.3 & 1.9 & 1.0 & 2.6 & 2.8 & 4.3 \\
\hline Vegetable oils & 4.7 & 17.1 & 7.8 & 9.2 & 12.6 & 13.5 \\
\hline Sweeteners & 2.7 & 9.4 & 9.1 & 10.1 & 17.4 & 10.5 \\
\hline Vegetables & 2.2 & 1.6 & 4.6 & 2.6 & 1.8 & 2.3 \\
\hline Alcoholic beverages & 1.8 & 1.7 & 8.0 & 5.5 & 1.0 & 5.9 \\
\hline Eggs & 1.4 & 1.7 & 1.1 & 2.7 & 1.4 & 1.4 \\
\hline Animal fats & 1.1 & 3.7 & 1.4 & 1.7 & 5.6 & 6.4 \\
\hline Fruits & 1.0 & 2.9 & 2.2 & 1.9 & 3.8 & 3.9 \\
\hline Pulses & 1.0 & 0.8 & 1.1 & 0.7 & 1.0 & 1.0 \\
\hline Fish, seafood & 0.8 & 3.2 & 2.8 & 6.4 & 0.8 & 1.1 \\
\hline Milk & 0.5 & 3.4 & 0.9 & 3.9 & 10.1 & 9.0 \\
\hline Stimulants & 0.0 & 0.6 & 0.1 & 0.7 & 0.4 & 0.6 \\
\hline Other & 2.6 & 4.0 & 4.3 & 5.6 & 5.9 & 2.4 \\
\hline
\end{tabular}

NOTE: EU(12) = the European Union's pre-1995 12 member countries: Belgium, Denmark, France, Germany, Greece, Ireland, Italy, Luxembourg, Netherlands, Portugal, Spain, and the United Kingdom. SOURCE: FAO 1996. 
1992, when the figure was 8 million ha. By 1993 the total sown area of soybeans had increased to over 12 million ha. This is equivalent to the combined areas for the production of vegetables, tobacco, sugar, and tea. In Heilongjiang, one-third of all cropland is used for the cultivation of soybeans; in provinces with much arable land, such as Henan and Sichuan, soybean cultivation has increased to between 4 percent and 6 percent of total cropland. A further trend toward meat-rich diets in China would trigger a corresponding decline in areas devoted to the cultivation of roots and tubers.

Parts of China's grasslands might be suitable for ranging additional cattle. Although far less popular than pork, beef is not unknown to Chinese cuisine, so it might be reasonable to consider the vast grasslands as one of the underutilized resources for food production. The main problem, however, is limited availability of water. Large herds of cattle would require the drilling of wells in dry areas. Even if there is enough water underground, massive ecological problems, like those experienced in the Sahel, could follow. Obviously, any expansion of pastoral systems in China has to take into account the close relationship between the productivity of livestock and existing ecological conditions. Pastoral systems can only increase production when they are adapted to the temperature, topography, availability of water, and vegetation and topsoil within the specific grassland area.

In addition to changes in diets, as people become more affluent they usually demand larger flats or move to suburban houses with gardens. Much economic growth would have to take place before Chinese cities expand into space-consuming suburbs. But even a modest increase in the demand for improved housing, and the likely splintering of large multi-generational Chinese households into nuclear-family households, are likely to boost land demand for urban housing. Between 1978 and 1995 the per capita living floor space had already increased from 3.6 to $8.1 \mathrm{~m}^{2}$ in urban areas and from 8.1 to $21.0 \mathrm{~m}^{2}$ in rural areas (Table 7 ).

China has recently reduced the number of working days per week from six to five. This immediately sparked a small-scale vacation boom. Recreational land use is still very small in China, but with increased wealth this will change. Official statistics already indicate a more than threefold increase in the per capita size of "public green areas" since 1980. Total passenger traffic in China has increased from 174 billion person $\mathrm{km}$ in 1978 to 900 billion person $\mathrm{km}$ in 1995 (Table 7).

In 1995, almost 6 million foreigners visited China, an increase of some 13 percent as compared to 1994 (International Herald Tribune 1996). Altogether China had 48.4 million tourist visits in 1995, the majority by expatriate Chinese from Hong Kong, Taiwan, and Macao who visited relatives and friends (Table 7). This influx of visitors not only generates earnings ( 209.8 billion yuan in 1995, or 3.6 percent of China's GDP) but will inevitably change attitudes and lifestyles. In China's largest cities, one can ob- 
serve Western-style weddings, beauty contests, gambling halls, cellular phones, fast-food restaurants, and luxury limousines (Zha 1995).

\section{Future political and economic conditions}

Future land use in China depends heavily on how the country's leaders pursue reform. China may follow a course of further economic liberalization and gradual progress toward democracy; civil conflict might be sparked by regional diversity and popular discontent with political and civil repression; or a post-Deng "strong man" or power elite might curb economic and political reforms and recentralize authority (Segal 1994; Lieberthal 1995a, 1995b; Lam 1995).

Under the most optimistic scenario, China would realize a unique achievement among the communist states of the twentieth century: a smooth transition from command to market economy, a gradual liberalization of society, and a peaceful transition to democracy (Overholt 1993). The China of the twenty-first century would be more open to the outside world, wealthier, and more regionally diverse. There would be more individual freedom, greater political participation and economic flexibility, but probably also more corruption and greater disparities in income and wealth (Lieberthal 1995a; 1995b; Miles 1995: 147ff).

Land use under this political scenario would be increasingly dominated by market mechanisms. Private owners and local government-not a remote central bureaucracy-would make the key decisions about land use. The price of land would greatly determine the purpose for which it is to be used (see World Bank 1993). Private farmland in close proximity to large cities and towns would be quickly converted into residential suburbs and commercial sites.

If China's agriculture moves toward a market system, consumer demand will primarily determine how the arable land is used. This is a clear lesson from Europe and Northern America. Thus, changes in income, food consumption, and other socioeconomic conditions would be major driving forces of land use.

We can assume that in the "economic growth" scenario just outlined, China's agricultural land-use patterns would be fragmented, highly variable, and regionally diverse, due to individual decisionmaking of landowners and changing consumer demand (Wang and Murie 1996). Much land would be transformed for urban use or as industrial sites. The rapidly growing industrial economy would require a significant expansion of transportation infrastructure, which would not only cut through cultivated areas, but also open up previously remote areas to settlement and resource exploitation. Much more land than today would be needed as parks and recreation areas for the expanding urban population. 
While most professional China observers predict continuous economic and political development for the country, adverse alternative scenarios cannot be overlooked (Krugman 1994; Hornik 1995). As Arthur Waldron (1995) has pointed out, "substantial-and not evolutionary or gradualchanges are not only possible but likely." The greatest threat to China's economic and political stability comes from within the system, namely the contradiction between economic liberalization and ongoing political control. China's small but growing middle class of successful managers, entrepreneurs, and professionals may resist the top-down control of the communist bureaucracy. Students and intellectuals may not be kept quiet forever. To compete in international markets, the economy needs competent mariagers who know the world. But those who are sent abroad have seen individual and political freedom and may demand some of the same back home. Equally explosive might be the rapidly growing regional diversity that is also a result of China's economic success. The country's vast size has always been a threat to its unity, but the threat will be even greater as the provinces drift further apart in their economic performance.

Another possibility for China, therefore, is that the leaders might recentralize the power structure. The land-use consequences of a return to central authority and communist economy would probably be a slowdown of urbanization-partly due to stricter control of mobility, partly due to a brake on urban economic growth. With a reestablishment of central planning, land cultivation would become more homogenous. In the current system of family farming, peasants have some incentives to increase productivity: they can use part of their production to generate private profits, by selling it either on urban markets or to state agencies. Hence, farmers will try to optimize land cultivation, a goal that is neither necessary nor possible with centralized political control, since land use is determined by a general economic plan.

\section{Conclusion}

I have identified five anthropogenic factors as major driving forces of landuse change in China: population growth, urbanization, industrialization, changes in lifestyles and consumption, and shifts in political and economic arrangements and institutions. A first set of empirical data has been collected and briefly described here to delineate the demographic and socioeconomic changes that are likely to affect future land use. I also presented further evidence that China's cultivated land area is more seriously underreported than previously recognized.

In the next half-century the population of China is likely to grow by some 300 million inhabitants. Rural-to-urban migration and the growth of cities and industrial infrastructure will be the dominant factors in land-use 
change, particularly in the densely settled eastern provinces. Lifestyle adjustments reflecting growing incomes and changing cultural influences will result in greater consumption of animal-based foods, demand for larger apartments or suburban houses, and a massive expansion in private means of transportation. Private farmland close to booming cities will be rapidly converted into residential and commercial sites. Finally, under the most optimistic political and economic conditions, China will be not only wealthier, but also more open to outside influences, and more regionally diverse. For such a development, greater income disparities will be one of the prices to pay.

\section{Notes}

The author thanks Gunther Fischer (IIASA), Nikos Alexandratos (FAO), and Chinese colleagues in the ILASA Land Use Change Project for helpful comments and suggestions.

1 The author is a senior research scholar in that project.
2 The term "individual" in this context does not mean "one person," but rather "one family." It is, however, the opposite of the term "collective," which is still an important principle of social organization in China.

\section{References}

Alexandratos, N. 1996. "China's projected cereals deficits in a world context," Agricultural Economics 15, no. 1: 1-16.

Ashton, B., K. Hill, A. Piazza, and R. Zeitz. 1984. "Famine in China, 1958-61," Population and Development Review 10, no. 4: 613-645.

Banister, J. 1987. China's Changing Population. Stanford: Stanford University Press.

Barnett, A. D. 1986. China's Modernization: Development and Reform in the 1980s. Joint Economic Committee of the Congress: China's Economy Looks Toward the Year 2000. Volume 1. Washington, D.C.: US Government Printing Office.

Baum, R. 1994. Burying Mao: Chinese Politics in the Age of Deng Xiaoping. Princeton: Princeton University Press.

Braudel, F. 1990. Sozialgeschichte des 15.-18. Jahrhunderts. Der Alltag. Munich: Kindler Verlag. (English edition: Capitalism and Material Life. New York: Harper and Row, 1973.)

Brown, L. 1995. Who Will Feed China? Wakeup Call for a Small Planet. New York: W. W. Norton. Cheng, C. (ed.). 1993. Climate and Agriculture in China. Beijing: China Meteorological Press.

Crook, F. 1993. Underreporting of China's Cultivated Land Area: Implications for World Agricultural Trade. USDA, International Agriculture and Trade Report, China. Washington, D.C.: ERS, USDA, Document RS-93-4.

Durand, J. D. 1960. “The population statistics of China, A.D. 2-1953," Population Studies 13, no. 3: 209-256.

Fang, J. W. and Z. Xie. 1994. "Deforestation in pre-industrial China: The Loess Plateau as an example," Chemosphere 29: 983-999.

FAO. 1996. FAOSTAT. Rome (Electronic Data Base).

Feeney, G. and J. Yuan. 1994. "Below replacement fertility in China? A close look at recent evidence," Population Studies 48, no. 3: 381-394.

Feeney, G. and F. Wang. 1993. "Parity progression and birth intervals in China: The influence of policy in hastening fertility decline," Population and Development Review 19, no. 1: $61-101$. 
Goldstein, S. 1990. "Urbanization in China, 1982-87: Effects of migration and reclassification," Population and Development Review 16, no. 4: 673-701.

Ge, J. 1993. "An estimate of the population size of the Ming dynasty in early 17th century," paper presented at the IUSSP General Conference, Session 40, Montreal.

Heilig, G. K. 1993. "Food, lifestyles, and energy," in Food and Nutrition Policy: Proceedings of the Second European Conference on Food and Nutrition Policy. The Hague, Netherlands, 21-24 April 1992, ed. D. G. van der Heij. Wageningen: Pydoc, pp. 60-86.

- 1994. "Neglected dimensions of global land-use change: Reflections and data," Population and Development Review 20, no. 4: 831-859.

- 1996. "How many people can be fed on earth?" in The Future Population of the World: What Can We Assume Today?, ed. W. Lutz. Revised and Updated Edition. London: Earthscan, pp. 196-249.

Ho, P. 1959. Studies on the Population of China, 1368-1953. Cambridge: Harvard University Press.

Hornik, R. 1995. "Bursting China's bubble," Foreign Affairs 73, no. 3: 28-42.

Huang, J., S. Rozelle, and M. Rosegrant. 1995. Supply, Demand and China's Future Grain Deficit. Washington, D.C.: International Food Policy Research Institute, draft report.

International Herald Tribune. 1994. "China to subsidize car purchases," 23 September (Reuters).

. 1995. "Mercedes-Benz seals $\$ 1$ billion China deal: Chrysler and Ford are beaten out for joint venture to build minivans," 13 July, p. 1 . 1996. "China says tourism is increasing," 2 May (Reuters).

Islam, N. (ed.). 1995. Population and Food in the Early Twenty-First Century. Washington, D.C.: International Food Policy Research Institute.

Jiang, Z., M. W. Feldman, and L. Zhang. 1995. "Population and development in China," paper presented at the Summer Session of the Aspen Global Change Institute.

Johnson, D. G. 1994. "Does China have a grain problem?" China Economic Review 4, no. 1.

Johnson, P. D. 1997. International Data Base. On-line data base. Washington, D.C.: International Programs Center, US Bureau of the Census.

Ke, B. 1996. "Grain production in China: Current trends, potentials and policy options," paper presented at the Conference on Feeding China: Today and into the 21 st Century, Harvard University, 1-2 March.

Kristof, N. D. and S. WuDunn. 1994. China Wakes: The Struggle for the Soul of a Rising Power. New York: Vintage.

Krugman, P. 1994. "The myth of Asia's miracle," Foreign Affairs 73, no. 6: 62-78.

Lam, W. W. 1995. China After Deng Xiaoping: The Power Struggle in Beijing Since Tiananmen. Singapore: John Wiley.

Li, H. 1994. Rural Workers Tiding in Urban Areas. Special Report 1.14. China Development Report. China Statistical Publishing House.

Lieberthal, K. 1995a. "A new China strategy," Foreign Affairs 74, no. 6: 35-49. 1995b. Governing China: From Revolution through Reform. New York: W. W. Norton.

Lutz, W., C. Prinz, and J. Langgassner. 1994. "The IIASA world population scenarios to 2030," in The Future Population of the World: What Can We Assume Today?, ed. W. Lutz. London: Earthscan, pp. 391-422.

Ma, L. J. C. and G. Cui. 1987. "Administrative changes and urban population in China," Annals of the Association of American Geographers 77, no. 3: 375-395.

Ma, L.J.C. and C. Lin. 1993. "Development of towns in China: A case study of Guangdong Province," Population and Development Review 19, no. 3: 583-606.

Mi, H. 1992. "The quantitative analysis about evolution of historical population on Ming Dynasty in China," paper presented at the IUSSP General Conference, Session 40, Montreal.

Miles, James A. R. 1995. The Legacy of Tiananmen: China in Disarray. Ann Arbor: University of Michigan Press.

Overholt, W. H. 1993. The Rise of China: How Economic Reform Is Creating a New Superpower. New York: W.W. Norton. 
Paarlberg, R. L. 1996. "Rice bowls and dust bowls: Africa, not China, faces a food crisis," Foreign Affairs 75, no. 3:127-132.

People's Republic of China. 1993. Population by County and City. Beijing: Ministry of Public Security.

Perkins, D. H. 1969. Agricultural Development in China, 1368-1968. Chicago: Aldine Publishing.

Rempel, H. 1996. China's Agricultural Sector: Emerging Trends and New Challenges: Department of Economics, University of Manitoba, the China Program of the Canadian International Development Agency.

Segal, G. 1994. "The Muddle Kingdom? China's changing shape," Foreign Affairs 73, no. 3: 43-58.

Smil, V. 1995. "Who will feed China?" The China Quarterly 143: 801-813.

State Science and Technology Commission, People's Republic of China. 1995. "Population, resources and environment in China." Special Issue of the China Science and Technology Newsletter, no. 49, 20 July.

Statistical Yearbook of China. Various years. Beijing: State Statistical Bureau.

Sun, H., et al. (eds.). 1994. Agriculture, Natural Resources and Regional Development in China. Nanjing: Jiangsu Science and Technology Press.

The Economist. 1995. 9 September, p. 63.

- 1996. "The long dive into the Middle Kingdom: Prospects for a motorized China," 8 June, pp. 69-70.

Topping, A. R. 1995. "Ecological roulette: Damming the Yangtze," Foreign Affairs 74, no. 5: 132-146.

Tuan, F. C. 1993. Recent Rural Development in China: Rich Coastal Versus Poor Inland Regions. USDA, International Agriculture and Trade Report, China. Washington, D.C.: ERS, USDA, Document RS-93-4.

Tyler, P. E. 1994. "China to churn out personal cars: Can its infrastructure and ecology stand the weight?" International Herald Tribune, 23 September.

UNDP/FAO/State Science and Technology Commission/State Land Administration. 1994. China: Land Resources, Use and Productivity Assessment. Main Report. Beijing (Technical Report of Project CPR/87/029).

United Nations 1995a. Urban Agglomerations, 1950-2015. The 1994 Revision. Machine-readable Data Sets. New York. - 1995b. Urban and Rural Areas, 1950-2025. The 1994 Revision. Machine-readable Data Sets. New York.

- 1995c. World Population Prospects, 1950-2050. The 1994 Revision. Magnetic Tape and Diskettes. New York.

1 1996. World Population Prospects: The 1996 Revision. New York (mimeographed).

Waldron, A. 1995. "After Deng the deluge: China's next leap forward," Foreign Affairs 74 , no. 5: 148-153.

Wang, T. et al. 1992. An Economic Analysis of the Progressive Decrease in the Quantity of China's Cultivated Land. Beijing: Jingji Kexue Chubanshe.

Wang, Y. P. and A. Murie. 1996. "The process of commercialisation of urban housing in China," Urban Studies 33, no. 6: 971-989.

World Bank 1993. China: Urban Land Management in an Emerging Market Economy. Washington, D.C.

Wu, C. and H. Guo (eds.). 1994. Land Use of China. Beijing: Science Press.

Yabuki, S. 1995. China's New Political Economy: The Giant Awakes. Boulder: Westview Press.

Zha, J. 1995. China Pop: How Soap Operas, Tabloids, and Bestsellers Are Transforming a Culture. New York: The New Press. 


\section{ORDERING INFORMATION}

Orders must include the publication number and should be sent to the Publications Department, International Institute for Applied Systems Analysis, A-2361 Laxenburg, Austria.

Telephone: +432236807

Telefax: +432236 71313

E-mail: molina@iiasa.ac.at

A full list of IIASA publications is available at http://www.iiasa.ac.at 
( 